\title{
Effect of glyphosate on hematological and biochemical parameters of Rabbit (Oryctolagus cuniculus)
}

Sanam Naz ${ }^{1 *}$, Razia Iqbal ${ }^{1}$, Aftab Ahmad ${ }^{2}$, Muhammad Faheem Malik ${ }^{1}$, Muhammad Jabbar ${ }^{3}$, Rashid Yaqoob ${ }^{4}$, Muhammad Saeed ${ }^{5}$, Abid Hussain ${ }^{6}$, Tahir Aziz ${ }^{6}$, Syed Usman Haider ${ }^{6}$ and Abdul Razaq ${ }^{6}$

1. Department of Zoology, University of Gujrat, Punjab-Pakistan

2. National Academy of Young Scientists (NAYS)-Pakistan

3. Department of Statistics, University of Gujrat, Punjab-Pakistan

4. Nawaz Sharif Medical College, University of Gujrat, Punjab-Pakistan

5. Quality Department, Ali Akbar Group/Pak China Chemicals Pvt. Ltd, Lahore-Pakistan

6. Directorate of Poultry Research Institute Rawalpindi-Pakistan

*Corresponding author's email: sanam.naz2016@gmail.com

Citation

Sanam Naz, Razia Iqbal, Aftab Ahmad, Muhammad Faheem Malik, Muhammad Jabbar, Rashid Yaqoob, Muhammad Saeed, Abid Hussain, Tahir Aziz, Syed Usman Haider and Abdul Razaq. Effect of glyphosate on hematological and biochemical parameters of Rabbit (Oryctolagus cuniculus). Pure and Applied Biology. Vol. 8, Issue 1, pp78-92. http://dx.doi.org/10.19045/bspab.2018.700166

Received: 03/07/2018

Revised: $27 / 09 / 2018$

Accepted: 05/10/2018

Online First: 12/10/2018

\section{Abstract}

To improve agriculture, herbicides are extensively used all over the world. In this study toxicity of glyphosate was assessed on rabbits. For this reason, 36 female rabbits were divided into four groups including treated and control having 9 rabbits in each. Three concentrations of glyphosate were selected as $\mathrm{BC} 1(50 \mathrm{mg} / \mathrm{kg} / \mathrm{bw}), \mathrm{BC} 2(100 \mathrm{mg} / \mathrm{kg} / \mathrm{bw})$ and BC3 $(150 \mathrm{mg} / \mathrm{kg} / \mathrm{bw})$ for treated groups and no any treatment for the control group C. For checking the herbicide effects hematological parameters including white blood cells (WBC), red blood cells (RBC), hemoglobin, hematocrit (HCT), mean corpuscular volume (MCV), mean corpuscular hemoglobin (MCH), mean corpuscular hemoglobin concentration (MCHC), and platelets and biochemical parameters including bilirubin, alanine aminotransferase (ALT), aspartate aminotransferase (AST), alkaline phosphatase, urea and creatinine were selected. The rabbits were exposed to glyphosate and effect of glyphosate was studied after 15,30 and 45 days of exposure. This study indicated that glyphosate showed remarkable toxicity for hematological and biochemical parameters under investigation and glyphosate toxicity was directly related to the increasing concentration and time of exposure.

Keywords: Biochemical parameters; Glyphosate; Hematological parameters; Herbicides or pesticides; Rabbit; Toxicity

\section{Introduction}

Glyphosate is a non-selective herbicide which is used to eradicate weeds efficiently without ploughing. In Kuwait its use is about $0.98 \mathrm{~kg}$ ai ha $\mathrm{ha}^{-1} /$ year. It inhibits the enzyme 5enolpyruvylshikimate-3-phosphate synthase which is involved in the shikimic acid (aromatic amino acid) metabolic pathway [14] and declared as less toxic as compared to some other herbicides [5].

Glyphosate is considered as environmentally friendly because their residues are easily 
degradable and highly adsorbed into soil which cause less leaching, but it remains on crops for longer time. Although, lot of evidences about its toxic effects on nontargeted organisms were observed. Many studies have exposed its negative effect on the vertebrates and on invertebrates. But it is the widely and utmost used herbicide in the world [2, 6-8].

Now a day's all over the world 90\% genetically modified glyphosate resistance crops are grown which has dramatically enhanced the use of glyphosate herbicide on crops as a result there is a vast indication of its residues in food material [9].

In milk its tolerated residue level is about $0.05 \mathrm{mg} / \mathrm{kg}$ reported from Europe. Glyphosate is considered as one of the primary main pollutant of aquatic system [10, 11]. As previously observed that even its very low amount of agriculture uses cause endocrine disruption in addition toxicity to kidney, liver cell line and human placenta [12-16].

Significant amount of glyphosate residues detected in urine of rabbits, human and cattle by Gas Chromatography-Mass Spectroscopy and ELISA. Fattening rabbits have higher number of residues. It is also observed in different organs including liver, lung, kidney, intestine, spleen and muscles of animals. It inhibits the cytochrome enzyme Cyp450, which is in charge for the formation of steroid hormones similarly it also affects some other P450 family enzymes, which is critical for xenobiotic metabolism. Several gut bacterial populations also get troubled by glyphosate [9]. It also inhibits the growth of food microorganisms and micro biodiversity of soil [11].

In June (1991) Environmental Protection Agency (EPA) declared that glyphosate was not carcinogenic [17]. But recently, in March (2015) World Health Organization (WHO) declared that glyphosate is carcinogenic and should be banned. Glyphosate have adverse effect on biological systems proved by previous studies such as DNA damage, glycine homeostasis disturbance, inhibition of enzyme succinate dehydrogenase, manganese chelation, variation in glyoxylate and N-nitrosoglyphosate. There are lot of evidences about glyphosate use on crops and resulting into multiple types of cancers including liver cancer, kidney cancer, bladder cancer, thyroid cancer, breast cancer, pancreatic cancer and leukemia etc. [18].

Higher degree of DNA damaged was observed in individuals exposed to glyphosate and show genotoxicity [19]. At molecular level study [20] indicate that glyphosate-based herbicides cause change in transcript cluster resulting into damage in kidney tissues and regeneration of liver followed by this change cause damage in the liver tissues. Oxidative and cellular stress is also caused by transcriptional changes due to toxic effect of glyphosate [21]. The present study was done to investigate the effect of glyphosate on animals at cellular level and to check the toxicity of this important herbicide.

\section{Materials and methods}

\section{Animals}

For this study colony of rabbits was established and 36 female rabbits were randomly chosen and divided into 4 groups having 9 animals in each including three treated groups $\mathrm{BC} 1, \mathrm{BC} 2, \mathrm{BC} 3$ and group $\mathrm{C}$ as control. Throughout study animals were kept in stain less steel cages, with temperature $\left(21 \pm 2^{\circ} \mathrm{C}\right)$, humidity $40-70 \%$ [22] and cage sanitation was daily. The animals were fed with Trifolium resupinatum $\mathrm{L}$. and tap water was for drinking.

\section{Herbicide}

For treatment herbicide glyphosate $(N$ (phosphonomethyl) glycine) was purchased from market. Glyphosate was $48 \%$ formulation having $48 \%$ glyphosate IPA (isopropylammonium) salt contents (Glyphosate contents was $36.30 \%$ ). Oral 
$\mathrm{LD}_{50}$ of glyphosate for rabbits is 5000 or 4000-6000mg/kg/bw [23].

Three concentrations $50 \mathrm{mg} / \mathrm{kg} / \mathrm{bw}$, $100 \mathrm{mg} / \mathrm{kg} / \mathrm{bw}$ and $150 \mathrm{mg} / \mathrm{kg} / \mathrm{bw}$ from $36.30 \% \mathrm{w} / \mathrm{v}$ formulation of glyphosate for $\mathrm{BC} 1, \mathrm{BC} 2$ and $\mathrm{BC} 3$ groups were selected, respectively. All doses of herbicide were measured and mixed with few drops of water for dilution and given by needleless syringe $10 \mathrm{cc}$ into each animal's mouth of treated groups for 45 days according to their body weights except group $\mathrm{C}$ which was kept as control.

\section{Blood sample collection}

Blood collection site was Jugular vein. Animals was warmed up at neck region by pouring warm water and then held at the site edge of table forelimb extending downward and head upward, needle was inserted, and blood was taken from each group at day $15^{\text {th }}$, $30^{\text {th }}$ and $45^{\text {th }}$.

\section{Hematological tests}

For CBC tests, $3 \mathrm{ml}$ blood was stored in CBC vails from each animal. Automated hematological analyzer made in Sweden (Medonic-M-series M32M) was used with hematological analysis by using commercial kits purchased from market (Merck Germany) [24]. Hematological analysis was done by coulter method [25].

\section{Biochemical tests}

For biochemical tests two gel tubes were used each time for individual animal having $2.5 \mathrm{ml}$ blood, respectively. For biochemical tests, blood samples were centrifuged at 3000rpm in centrifuge machine for 10 minutes [26] and then stored at $2-8^{\circ} \mathrm{C}$ until analysis. Chemistry analyzer (Microlab 400 S.N 16-60018) was used for analysis by using diagnostic commercial kits purchased from market (Merck Germany) [24]. Bilirubin, AST, ALT, ALP levels were measured by method of $[26,27]$ urea level was measured by method [28] and creatinine level by Jeffe method [29].

\section{Statistical analysis}

Statistical analysis was done by using software (IBM SPSS V21.0.) One-way ANOVA was used followed by post hoc test Least Significant Difference test (LSD), whose results were mentioned by different letters at significant level $(\mathrm{p} \leq 0.05)$

\section{Results}

\section{Hematological parameters}

For WBC at day $15^{\text {th }} \mathrm{BC} 1$ and $\mathrm{BC} 2$ $(8.57 \pm 0.00,9.20 \pm 0.05)$ have no significant difference with control $\mathrm{C}(8.50 \pm 0.57)$ but BC3 (10.40 \pm 0.05$)$ significantly increased WBCs with respect to control. At $30^{\text {th }}$ and $45^{\text {th }}$ day $\mathrm{BC} 1 \quad(9.78 \pm 0.00$ and $9.40 \pm 0.11)$ have no difference with control C $(9.40 \pm 0.05$, $7.40 \pm 0.11)$, respectively. $\mathrm{BC} 2$ and $\mathrm{BC} 3$ $(10.50 \pm 0.57,10.90 \pm 0.05)$ and $(11.03 \pm 0.57$, $12.00 \pm 1.15$ ) have significant difference with control C. Overall WBC count increased with increasing concentration (Figure 1).

The RBC count at day $15^{\text {th }}$ there was no significant difference of $\mathrm{BC} 1, \mathrm{BC} 2, \mathrm{BC} 3$ $(6.40 \pm 0.11, \quad 6.37 \pm 0.01, \quad 6.26 \pm 0.00)$ with control C (6.70 \pm 0.57$)$. At day $30^{\text {th }}$ and $45^{\text {th }}$ $(5.81 \pm 0.00, \quad 5.73 \pm 0.01, \quad 5.60 \pm 0.05)$ and $(5.23 \pm 0.00, \quad 5.01 \pm 0.00, \quad 4.98 \pm 0.00)$ have significant difference with control $\mathrm{C}$ $(6.82 \pm 0.05,6.60 \pm 0.05)$, respectively. RBCs number significantly decreased with increasing concentration (Figure 2).

The hemoglobin at $15^{\text {th }}$ day $\mathrm{BC} 1$ have no significant difference with control C $(12.10 \pm 0.05)$ but BC2, BC3 (11.80 \pm 0.05 , $11.40 \pm 0.05)$ significantly decreased with respect to control. At day $30^{\text {th }}$ there was no significant difference of $\mathrm{BC} 1, \mathrm{BC} 2$ with

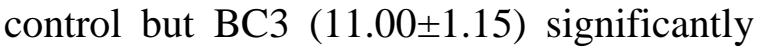
decreased hemoglobin level compared to control C (13.60 \pm 0.11$)$. At day $45^{\text {th }}$ all $\mathrm{BC} 1$, BC2， BC3 (12.30 $\pm 0.05, \quad 11.70 \pm 0.05$, $10.50 \pm 0.05)$ significantly decreased in hemoglobin level with respect to control C (12.90 \pm 0.05$)$. Overall hemoglobin level decreased with increasing concentration (Figure 3). 
The HCT level at day $15^{\text {th }} \mathrm{BC} 1$ have no significant difference with control but $\mathrm{BC} 2$, BC3 (39.10 $\pm 0.05, \quad 39.00 \pm 0.57)$ had significant difference with control $\mathrm{C}$ (41.70 \pm 0.05$)$. At day $30^{\text {th }}, 45^{\text {th }}$ all BC1, BC2, BC3 (39.00 $\pm 1.15,38.30 \pm 0.05,38.00 \pm 0.57)$ and $(38.80 \pm 0.05,37.60 \pm 0.57,36.70 \pm 0.05)$ have significant decreased with respect to control C $(43.60 \pm 0.00,42.60 \pm 0.05)$, respectively. HCT level decreased with increasing concentration (Figure 4).

The MCV level at day $15^{\text {th }} \mathrm{BC} 1, \mathrm{BC} 2, \mathrm{BC} 3$ $(61.70 \pm 0.11,61.40 \pm 0.05,60.10 \pm 0.05)$ all have significant difference with control $\mathrm{C}$ (62.20 \pm 0.05$)$. At day $30^{\text {th }}$ and $45^{\text {th }}(61.50 \pm 0.05,61.30 \pm 0.05,61.10 \pm 0.57)$ and $(62.30 \pm 0.00,61.60 \pm 0.05,61.30 \pm 0.57)$ all have significant difference with control $\mathrm{C}$ $(63.90 \pm 0.57, \quad 64.50 \pm 0.05), \quad$ respectively (Figure 5).

The MCH level at day $15^{\text {th }}$ and $30^{\text {th }}$ day of BC1, BC2, BC3 (18.70 $\pm 0.05,18.50 \pm 0.05$, $18.10 \pm 0.57)$ and $(19.70 \pm 0.05,19.20 \pm 0.05$, $19.10 \pm 0.05)$ significantly decreased in $\mathrm{MCH}$ level compared to control C $(19.80 \pm 0.05$, $9.90 \pm 0.05)$, respectively. At day $45^{\text {th }} \mathrm{BC} 1$, BC2 $(20.10 \pm 0.57,19.80 \pm 0.05)$ have no significant difference with control C

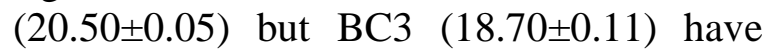
significant difference with control C. Overall decreased in $\mathrm{MCH}$ level was observed (Figure 6).

The MCHC level at day $15^{\text {th }} \mathrm{BC} 1$ (29.60 \pm 0.05$)$ had no significant difference with control C $(30.00 \pm 0.05)$ but BC2, BC3 $(28.50 \pm 0.05,28.00 \pm 0.57)$ had significant difference by decreasing MCHC level with respect to control C. At day $30^{\text {th }}$ and $45^{\text {th }} \mathrm{BC} 1, \quad \mathrm{BC} 2, \quad \mathrm{BC} 3 \quad(30.60 \pm 0.05$, $29.80 \pm 0.05,28.40 \pm 0.05)$ and $(30.30 \pm 0.05$, $29.20 \pm 0.05,27.03 \pm 0.00)$ had significant difference with control C (31.10 \pm 0.05 , $31.50 \pm 0.05$ ), respectively (Figure 7 ).

The number of platelets at $15^{\text {th }}$ and $30^{\text {th }}$ day BC1, BC2, BC3 $(347.00 \pm 1.15,395.00 \pm 0.57$, $425.00 \pm 1.15) \quad$ and $\quad(352.00 \pm 1.15$,
$406.00 \pm 0.57, \quad 436.00 \pm 0.57)$ all have significant difference with control C $(341.00 \pm 1.15,339.00 \pm 0.57)$, respectively. At $45^{\text {th }}$ day BC1 $(343.00 \pm 0.57)$ have no any significant difference with control C

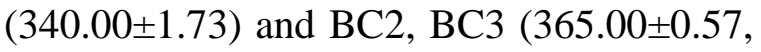
$453.00 \pm 0.57)$ have significantly increased number of platelets compared to control $\mathrm{C}$ (Figure 8).

\section{Biochemical parameters}

The Bilirubin level of rabbits for glyphosate (B) at day $15^{\text {th }} \mathrm{BC} 1, \mathrm{BC} 2, \mathrm{BC} 3(0.90 \pm 0.05$, $0.90 \pm 0.05,0.90 \pm 0.05)$, respectively have no significant difference with each other and with control $\mathrm{C}(0.80 \pm 0.05)$. At day $30^{\text {th }} \mathrm{BC} 1$, BC2 $(0.90 \pm 0.05,0.90 \pm 0.05)$, respectively had no significant difference with control $\mathrm{C}$ $(0.80 \pm 0.05)$ but $\mathrm{BC} 3 \quad(1.00 \pm 0.05)$ had significantly increased in bilirubin level compared to control C. At $45^{\text {th }}$ day BC2 and

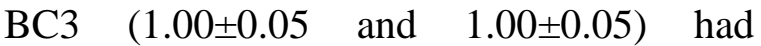
significantly increased in bilirubin level compared to control C $(0.80 \pm 0.05) \mathrm{BC} 1$ $(0.90 \pm 0.00)$ had no significance difference with control C. Overall increase in level was observed as compared to control C (Figure 9).

The ALT level difference was observed of three concentrations of treatment B glyphosate at $15^{\text {th }}, 30^{\text {th }}$ and $45^{\text {th }}$ day. At $15^{\text {th }}$ day $\mathrm{BC} 1, \mathrm{BC} 2$ and $\mathrm{BC} 3(167.00 \pm 0.57$, $178.00 \pm 0.57$ and $196.00 \pm 0.57$ ), respectively significantly increased ALT level with respect to control $\mathrm{C}(156.00 \pm 1.15)$ and have difference with each other. At day $30^{\text {th }} \mathrm{BC} 1$ (179.60 \pm 0.11$)$ had no significant difference with control C $(179.00 \pm 1.73)$ but had significant difference with treated groups. BC2 and BC3 (203.00 \pm 0.57 and $246.70 \pm 0.05$ ) had significant difference with each other and with control $\mathrm{C}$ by increasing ALT level. At day $45^{\text {th }} \mathrm{BC} 1, \mathrm{BC} 2$ and BC3 $(212.00 \pm 1.15, \quad 298.00 \pm 0.57 \quad$ and $313.60 \pm 0.57$ ), respectively had significant difference with each other and with control $\mathrm{C}$ (165.00 \pm 1.15$)$. Significant increase in ALT 
level was observed with respect to control and with increasing concentration of herbicide (Figure 10).

The AST level for glyphosate (B) at $15^{\text {th }}$ day for BC1 $(149.70 \pm 0.05)$ had no significant difference with control C (148.00 \pm 1.15$)$ but have significant difference with treated groups. But $\mathrm{BC} 2, \mathrm{BC} 3 \quad(157.90 \pm 0.05$, $199.00 \pm 0.57)$ shows significant difference with control and with each other. At day 30 and 45 the $\mathrm{BC} 1, \quad \mathrm{BC} 2, \quad \mathrm{BC} 3$ $(193.00 \pm 0.57,207.70 \pm 0.05, \quad 278.00 \pm 0.57)$ and $\quad(192.30 \pm 0.57, \quad 335.00 \pm 1.15$, $366.30 \pm 0.05)$ had significant differences with control C $\quad(184.00 \pm 0.57$ and $167.00 \pm 0.57)$, respectively and with each other (Figure 11).

The Alkaline phosphatase (ALP) level for glyphosate (B) at $15^{\text {th }}$ and $30^{\text {th }}$ day $\mathrm{BC}$, BC2, BC3 (256.00 $\pm 0.57, \quad 277.00 \pm 0.57$, $301.00 \pm 1.15) \quad$ and $\quad(259.00 \pm 0.57$, $279.00 \pm 0.57, \quad 308.50 \pm 0.05)$ all had significant difference with control C (234.00 \pm 1.15 and $227.00 \pm 0.57)$, respectively and with each other. At $45^{\text {th }}$ day $\mathrm{BC} 1$ (213.40 \pm 0.11$)$ had no significant difference

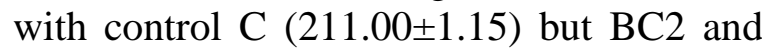

BC3 $\quad(280.70 \pm 0.05, \quad 312.00 \pm 1.15)$ have significant difference with each other and with control. It increased with increasing concentration (Figure 12).

The Urea level for glyphosate (B) in all $15^{\text {th }}$, $30^{\text {th }}$ and $45^{\text {th }}$ day for $\mathrm{BC} 1, \mathrm{BC} 2, \mathrm{BC} 3$ $(47.00 \pm 1.73, \quad 56.00 \pm 1.15, \quad 67.00 \pm 1.15)$, $(43.00 \pm 0.57,66.00 \pm 2.30,69.00 \pm 1.15)$ and $(46.70 \pm 0.05,67.00 \pm 0.57,69.80 \pm 0.05)$ had significant difference compared to control C $(37.00 \pm 1.15,36.00 \pm 1.15$ and $35.00 \pm 0.57$ ), respectively. With the increase in concentration of glyphosate there was an increase in urea level (Figure 13).

The creatinine level at $15^{\text {th }}$ day for $\mathrm{BC} 1$, $\mathrm{BC} 2$, BC3 $(1.20 \pm 0.05,1.20 \pm 0.05,1.30 \pm 0.05)$ all had significant results and creatinine level increased with respect to control $\mathrm{C}$ $(1.00 \pm 0.05)$ was detected. At $30^{\text {th }}$ and $45^{\text {th }}$ day $\mathrm{BC} 2$, BC3 $(1.50 \pm 0.05,1.60 \pm 0.05)$ and $(1.60 \pm 0.05,1.70 \pm 0.00)$ have significantly increased creatinine level compared to control C $(1.00 \pm 0.05, \quad 1.10 \pm 0.11)$, respectively but $\mathrm{BC} 1$ had no difference with control. Creatinine level increased with increasing concentration of glyphosate (Figure 14).

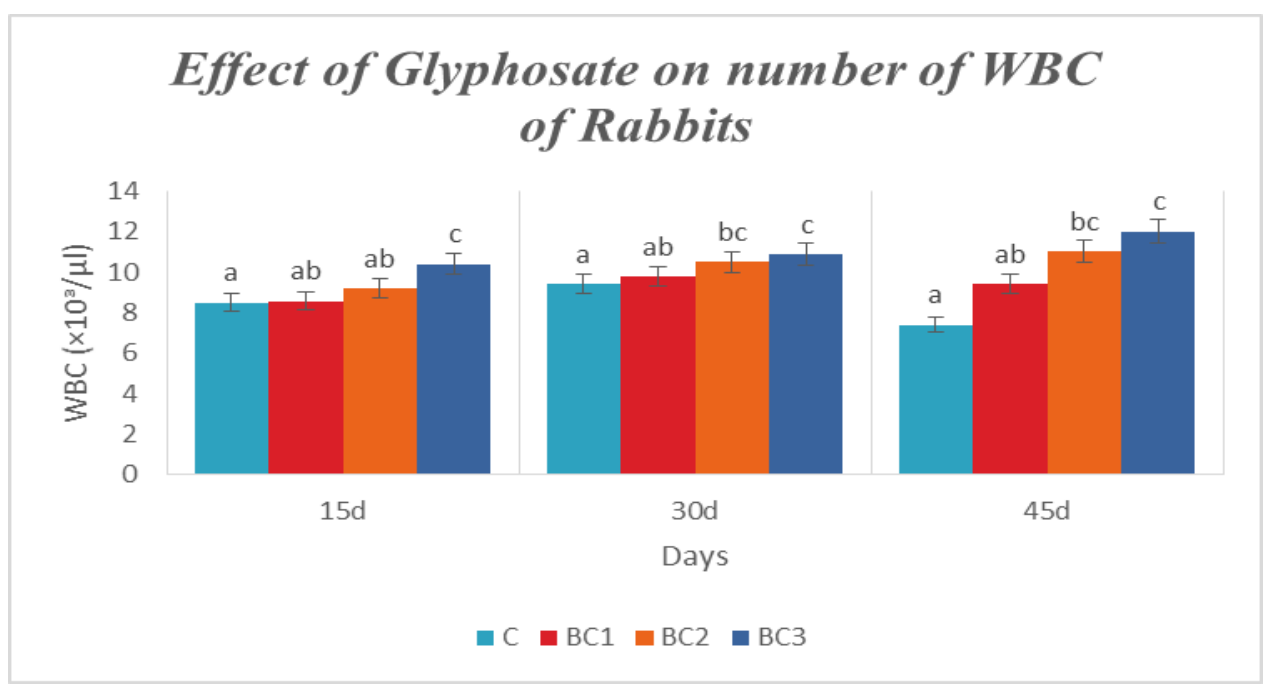

Figure 1. Number of white blood cells (WBCs) of rabbits in $C$ (control) and different concentration groups $B C 1(50 \mathrm{mg} / \mathrm{kg} / \mathrm{bw}), B C 2(100 \mathrm{mg} / \mathrm{kg} / \mathrm{bw})$ and $B C 3(150 \mathrm{mg} / \mathrm{kg} / \mathrm{bw})$ of treatment $B$ (Glyphosate) at $15^{\text {th }}, 30^{\text {th }}$ and $45^{\text {th }}$ day. Bars with different letters are significantly different $(\mathbf{p} \leq \mathbf{0 . 0 5})$ 


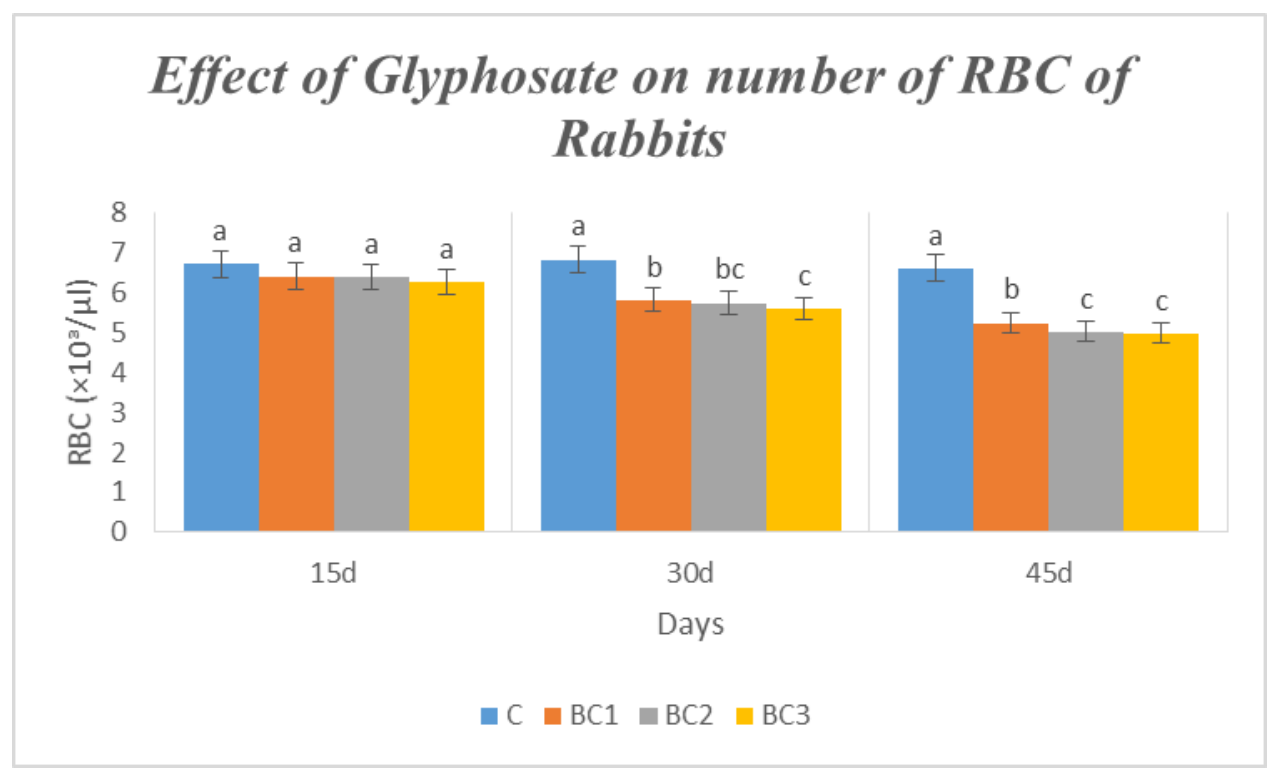

Figure 2. Total red blood cells (RBCs) of rabbits in $\mathrm{C}$ (control) and different concentration groups BC1 $(50 \mathrm{mg} / \mathrm{kg} / \mathrm{bw}), B C 2(100 \mathrm{mg} / \mathrm{kg} / \mathrm{bw})$ and $B C 3(150 \mathrm{mg} / \mathrm{kg} / \mathrm{bw})$ of treatment $B$ (Glyphosate) at $15^{\text {th }}, \mathbf{3 0}^{\text {th }}$ and $45^{\text {th }}$ day. Bars with different letters are significantly different $(\mathbf{p} \leq \mathbf{0 . 0 5})$

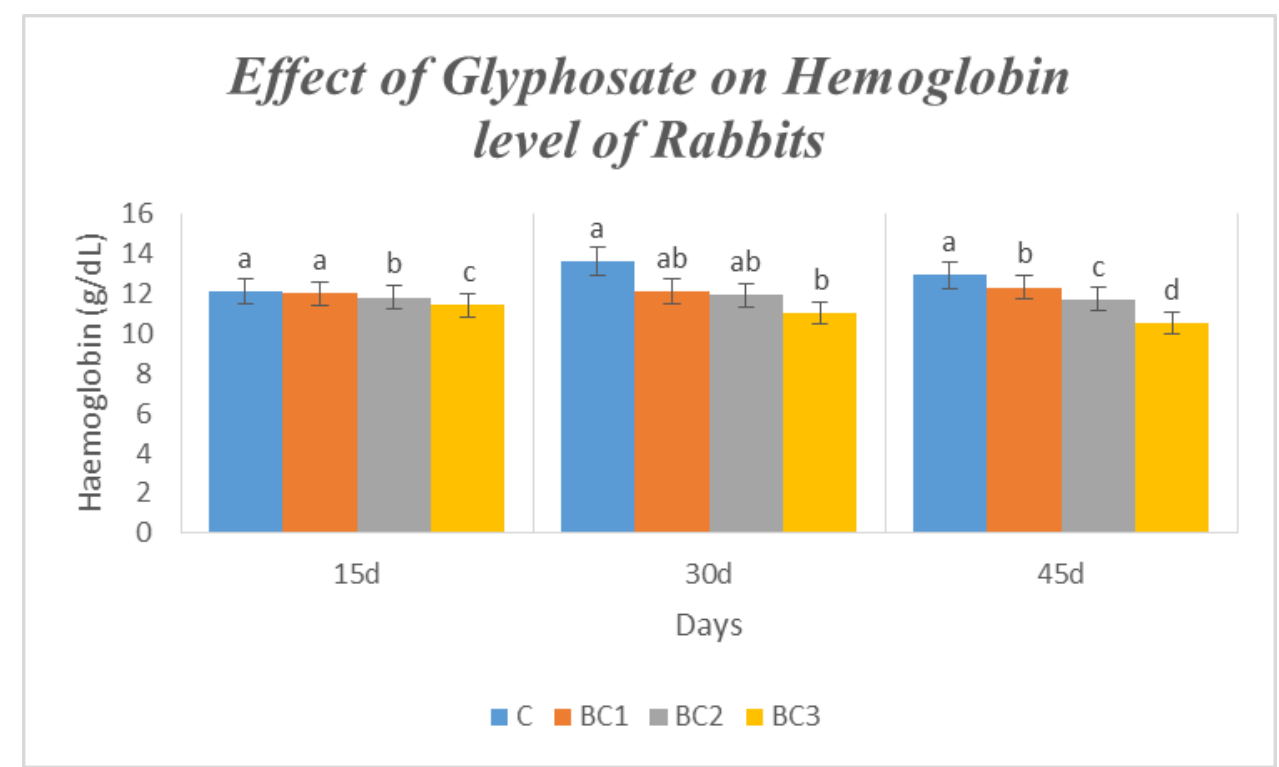

Figure 3. Hemoglobin level of rabbits in $\mathrm{C}$ (control) and different concentration groups BC1 $(50 \mathrm{mg} / \mathrm{kg} / \mathrm{bw}), B C 2(100 \mathrm{mg} / \mathrm{kg} / \mathrm{bw})$ and BC3 $(150 \mathrm{mg} / \mathrm{kg} / \mathrm{bw})$ of treatment B (Glyphosate) at $15^{\text {th }}, \mathbf{3 0}^{\text {th }}$ and $45^{\text {th }}$ day. Bars with different letters are significantly different $(p \leq 0.05)$ 


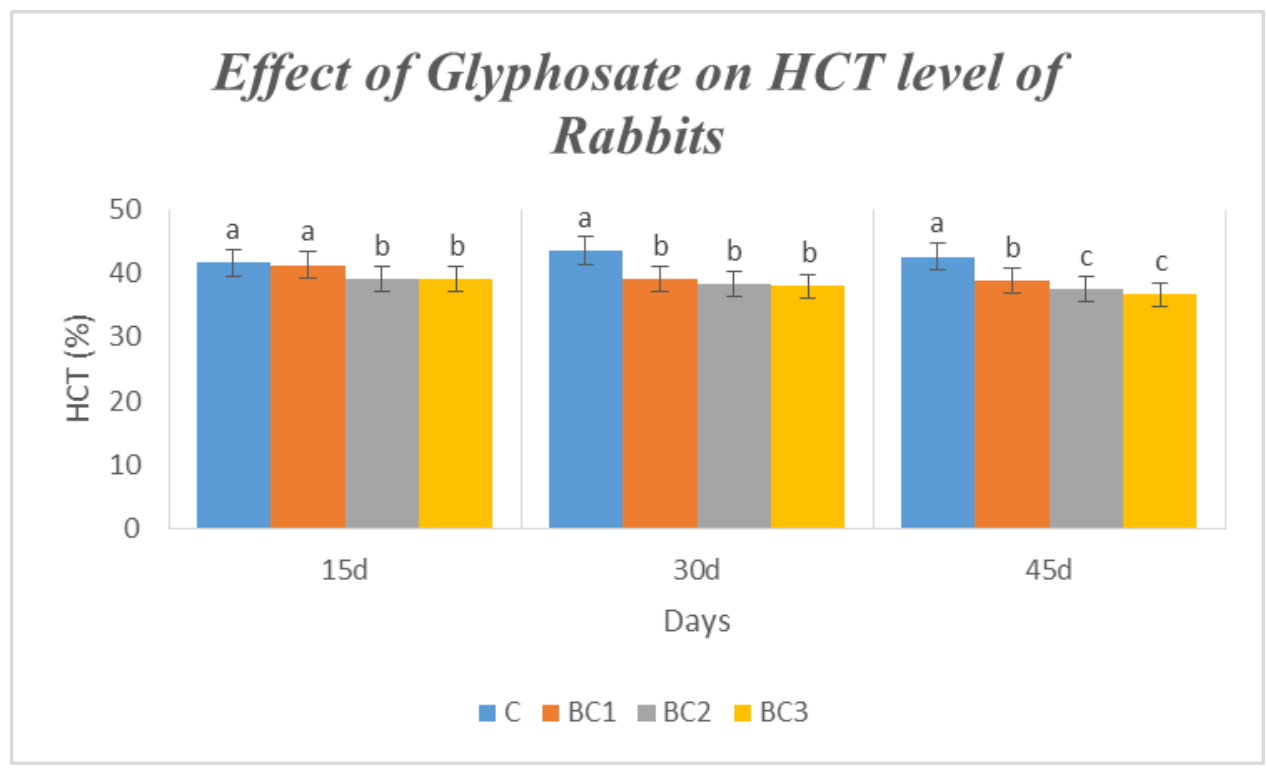

Figure 4. Hematocrits (HCT) of rabbits in $\mathrm{C}$ (control) and different concentration groups BC1 $(50 \mathrm{mg} / \mathrm{kg} / \mathrm{bw}), \quad B C 2(100 \mathrm{mg} / \mathrm{kg} / \mathrm{bw})$ and $\mathrm{BC3}(150 \mathrm{mg} / \mathrm{kg} / \mathrm{bw})$ of treatment $B$ (Glyphosate) at $15^{\text {th }}, 30^{\text {th }}$ and $45^{\text {th }}$ day. Bars with different letters are significantly different $(\mathbf{p} \leq \mathbf{0 . 0 5})$

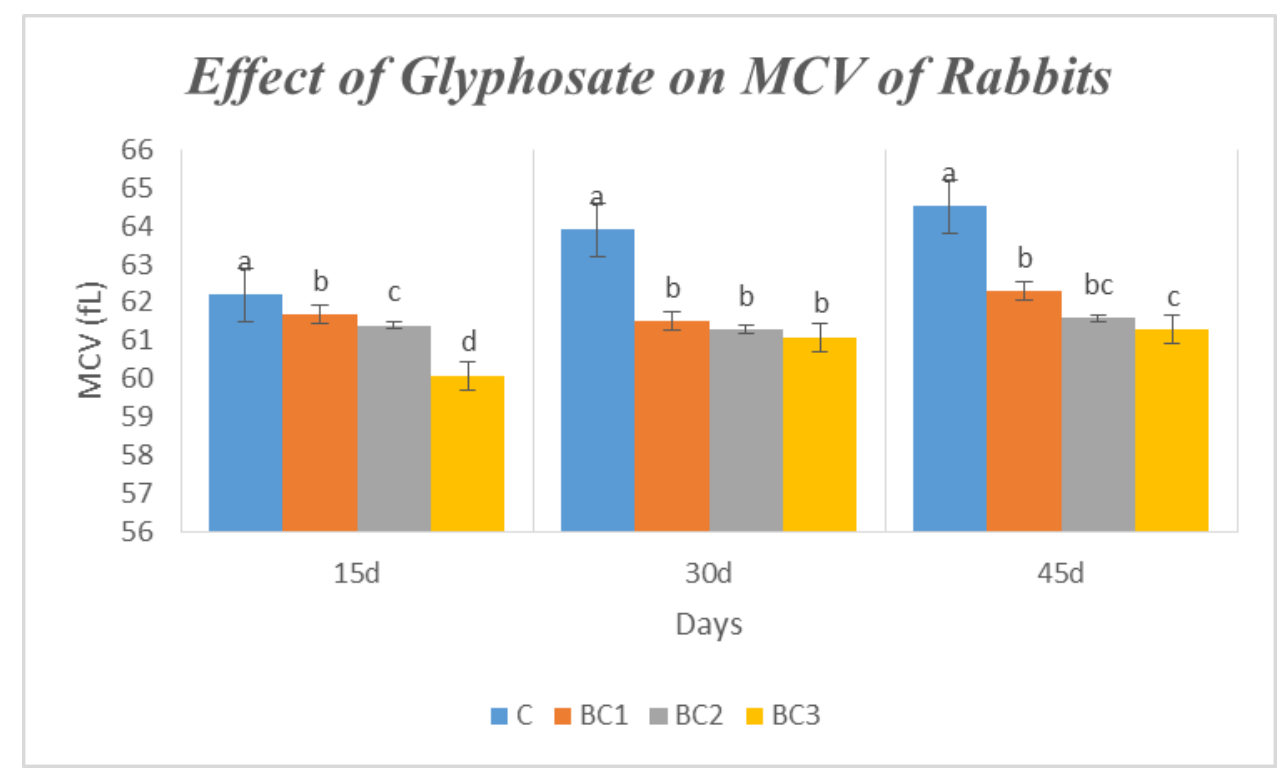

Figure 5. Mean corpuscular volume (MCV) of rabbits in $\mathrm{C}$ (control) and different concentration groups BC1 $(50 \mathrm{mg} / \mathrm{kg} / \mathrm{bw})$, BC2 $(100 \mathrm{mg} / \mathrm{kg} / \mathrm{bw})$ and BC3 $(150 \mathrm{mg} / \mathrm{kg} / \mathrm{bw})$ of treatment $B$ (Glyphosate) at $15^{\text {th }}, 30^{\text {th }}$ and $45^{\text {th }}$ day. Bars with different letters are significantly different $(\mathbf{p} \leq \mathbf{0 . 0 5})$ 


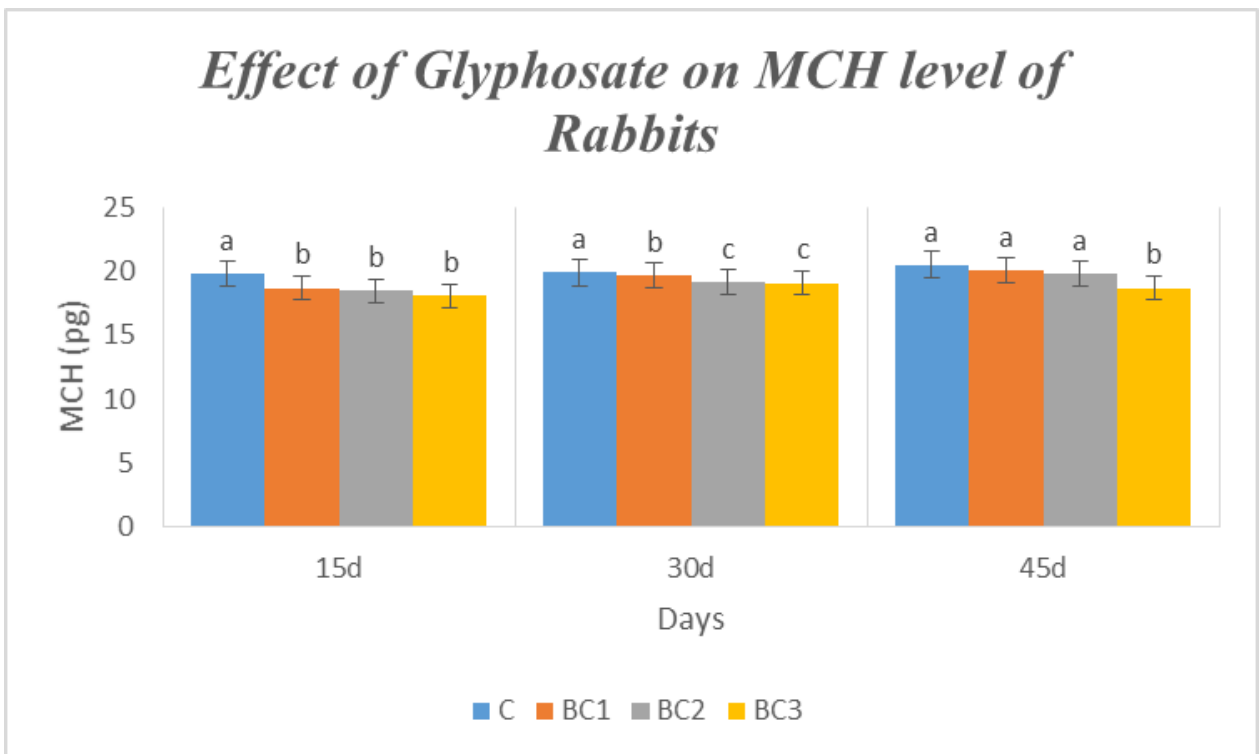

Figure 6. Mean Corpuscular Hemoglobin (MCH) of rabbits in $\mathrm{C}$ (control) and different concentration groups BC1 $(50 \mathrm{mg} / \mathrm{kg} / \mathrm{bw}), B C 2(100 \mathrm{mg} / \mathrm{kg} / \mathrm{bw})$ and $B C 3(150 \mathrm{mg} / \mathrm{kg} / \mathrm{bw})$ of treatment $B$ (Glyphosate) at $15^{\text {th }}, 30^{\text {th }}$ and $45^{\text {th }}$ day. Bars with different letters are significantly different $(\mathbf{p} \leq \mathbf{0 . 0 5})$

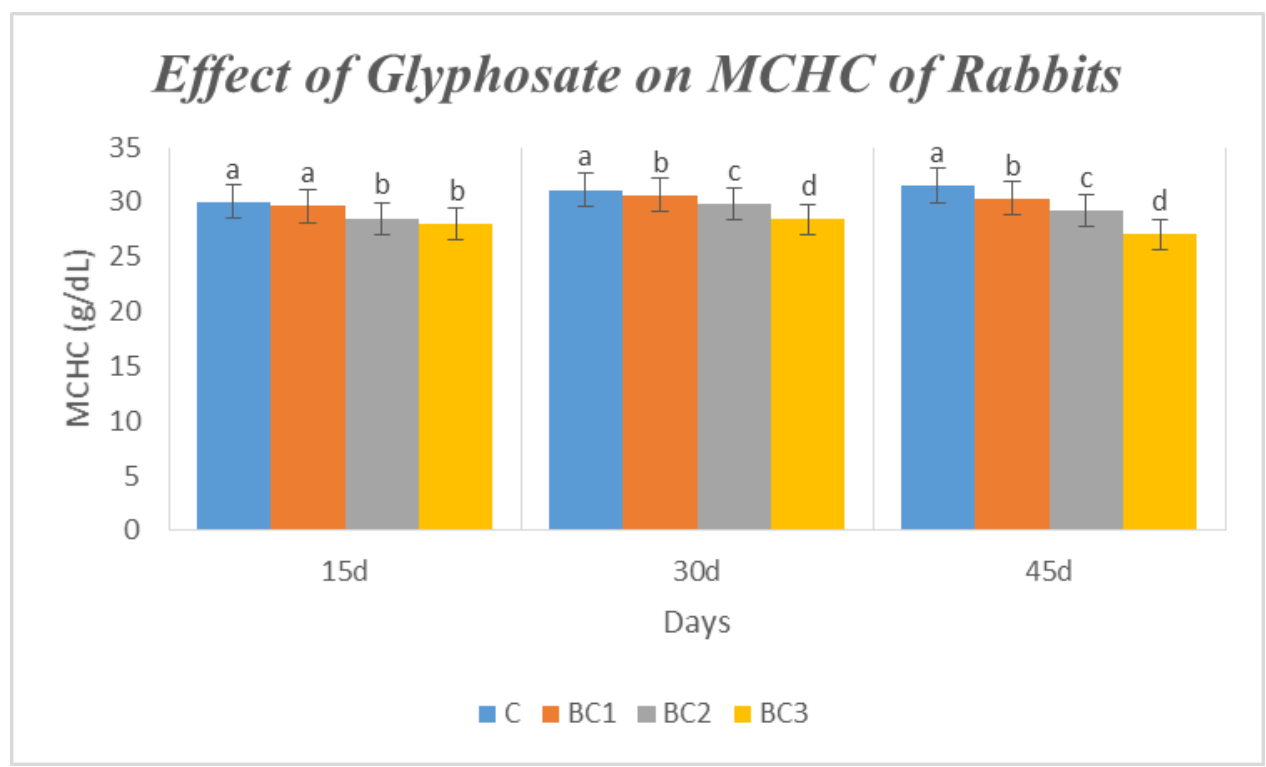

Figure 7. Mean Corpuscular Hemoglobin Concentration (MCHC) of rabbits in C(control) and different concentration groups BC1 $(50 \mathrm{mg} / \mathrm{kg} / \mathrm{bw}), \mathrm{BC} 2(100 \mathrm{mg} / \mathrm{kg} / \mathrm{bw})$ and $\mathrm{BC3}$ $(150 \mathrm{mg} / \mathrm{kg} / \mathrm{bw})$ of treatment $B$ (Glyphosate) at $15^{\text {th }}, 30^{\text {th }}$ and $45^{\text {th }}$ day. Bars with different letters are significantly different $(p \leq 0.05)$ 


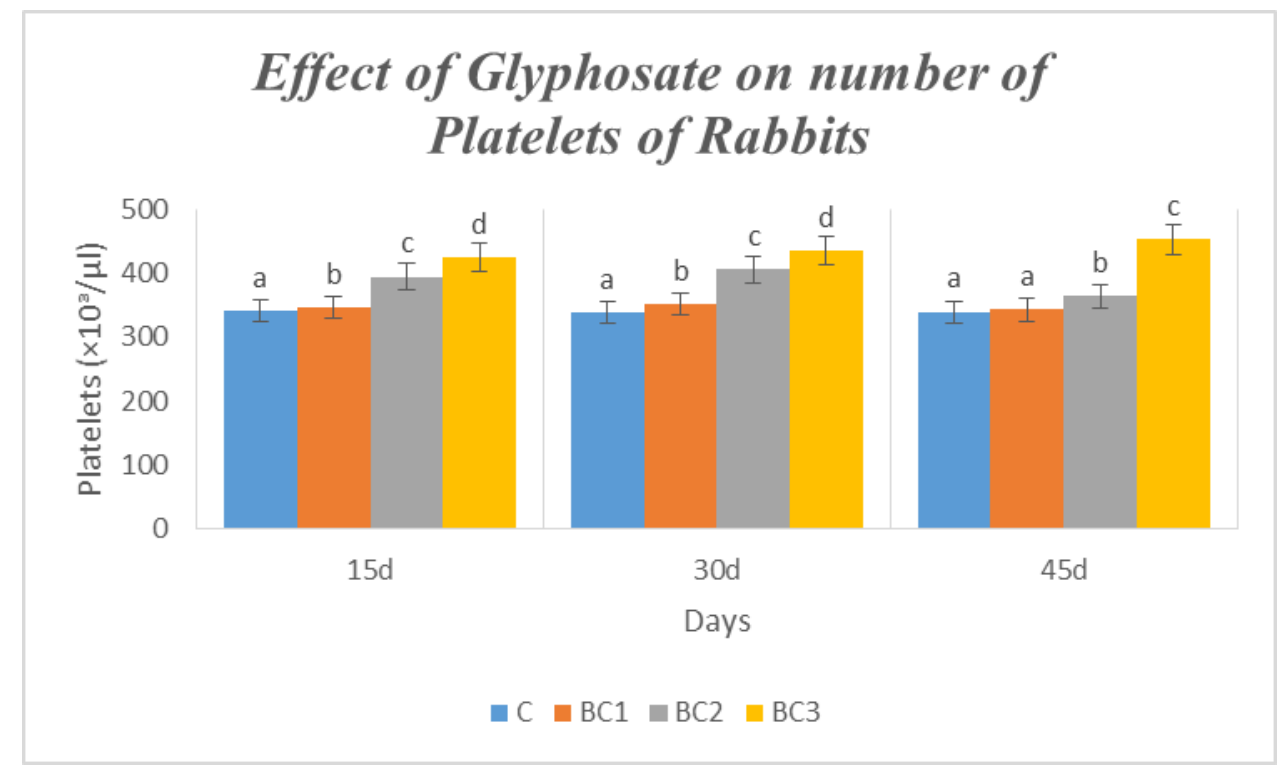

Figure 8. No of platelets of rabbits in $\mathrm{C}$ (control) and different concentration groups $\mathrm{BC} 1$ $(50 \mathrm{mg} / \mathrm{kg} / \mathrm{bw}), \mathrm{BC} 2(100 \mathrm{mg} / \mathrm{kg} / \mathrm{bw})$ and BC3 $(150 \mathrm{mg} / \mathrm{kg} / \mathrm{bw})$ of treatment B (Glyphosate) at $15^{\text {th }}, 30^{\text {th }}$ and $45^{\text {th }}$ day. Bars with different letters are significantly different $(p \leq 0.05)$

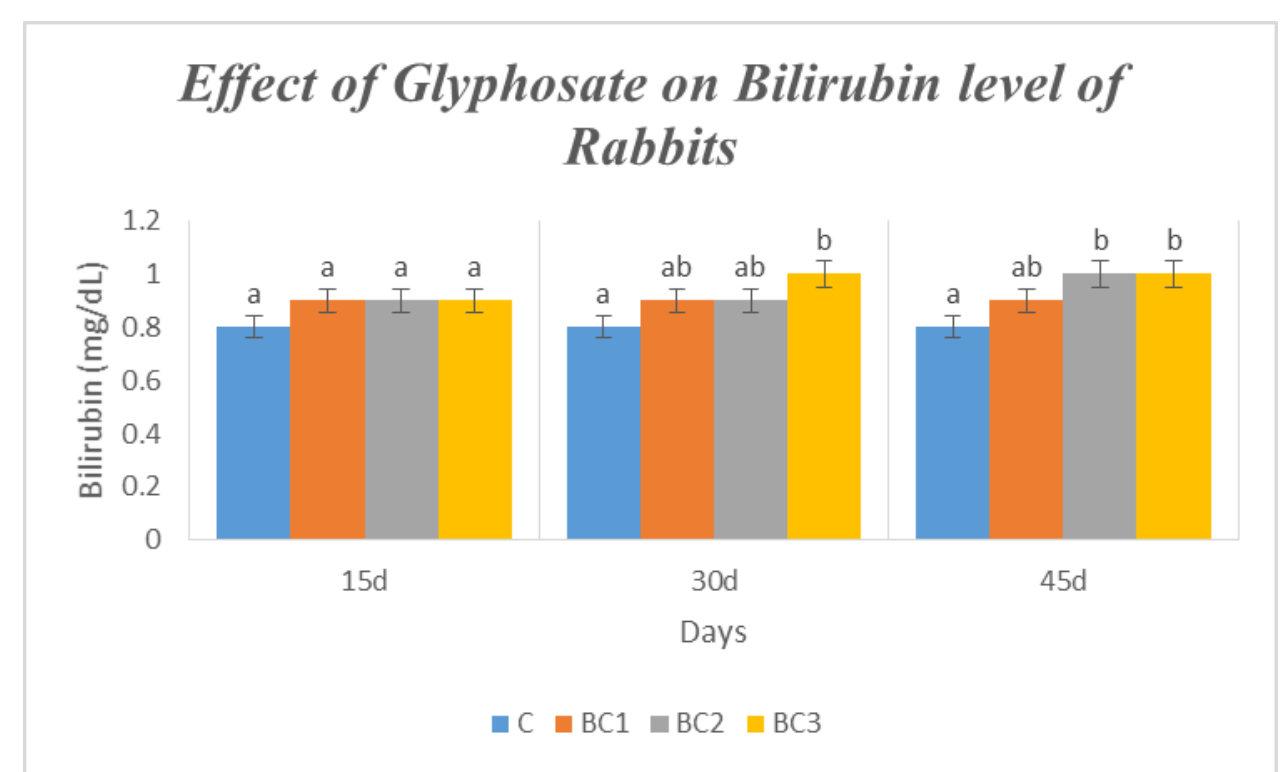

Figure 9. Bilirubin level of rabbits in $\mathrm{C}$ (control) and different concentration groups $\mathrm{BC1}$ $(50 \mathrm{mg} / \mathrm{kg} / \mathrm{bw}), B C 2(100 \mathrm{mg} / \mathrm{kg} / \mathrm{bw})$ and BC3 $(150 \mathrm{mg} / \mathrm{kg} / \mathrm{bw})$ of treatment B (Glyphosate) at $15^{\text {th }}, 30^{\text {th }}$ and $45^{\text {th }}$ day. Bars with different letters are significantly different $(p \leq 0.05)$ 


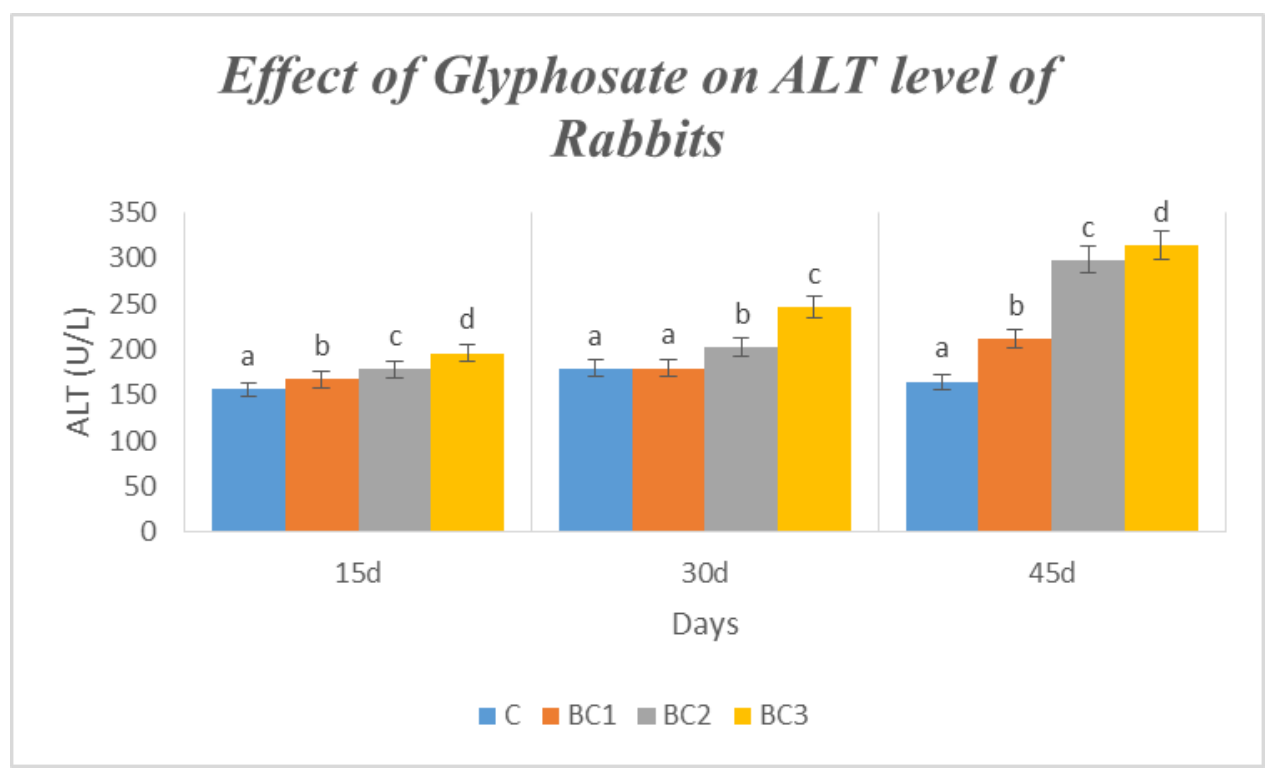

Figure 10. Alanine aminotransferase (ALT) level of rabbits in $\mathrm{C}$ (control) and different concentration groups BC1 $(50 \mathrm{mg} / \mathrm{kg} / \mathrm{bw}), B C 2(100 \mathrm{mg} / \mathrm{kg} / \mathrm{bw})$ and $B C 3(150 \mathrm{mg} / \mathrm{kg} / \mathrm{bw})$ of treatment $B$ (Glyphosate) at $15^{\text {th }}, 30^{\text {th }}$ and $45^{\text {th }}$ day. Bars with different letters are significantly different $(\mathbf{p} \leq \mathbf{0 . 0 5})$

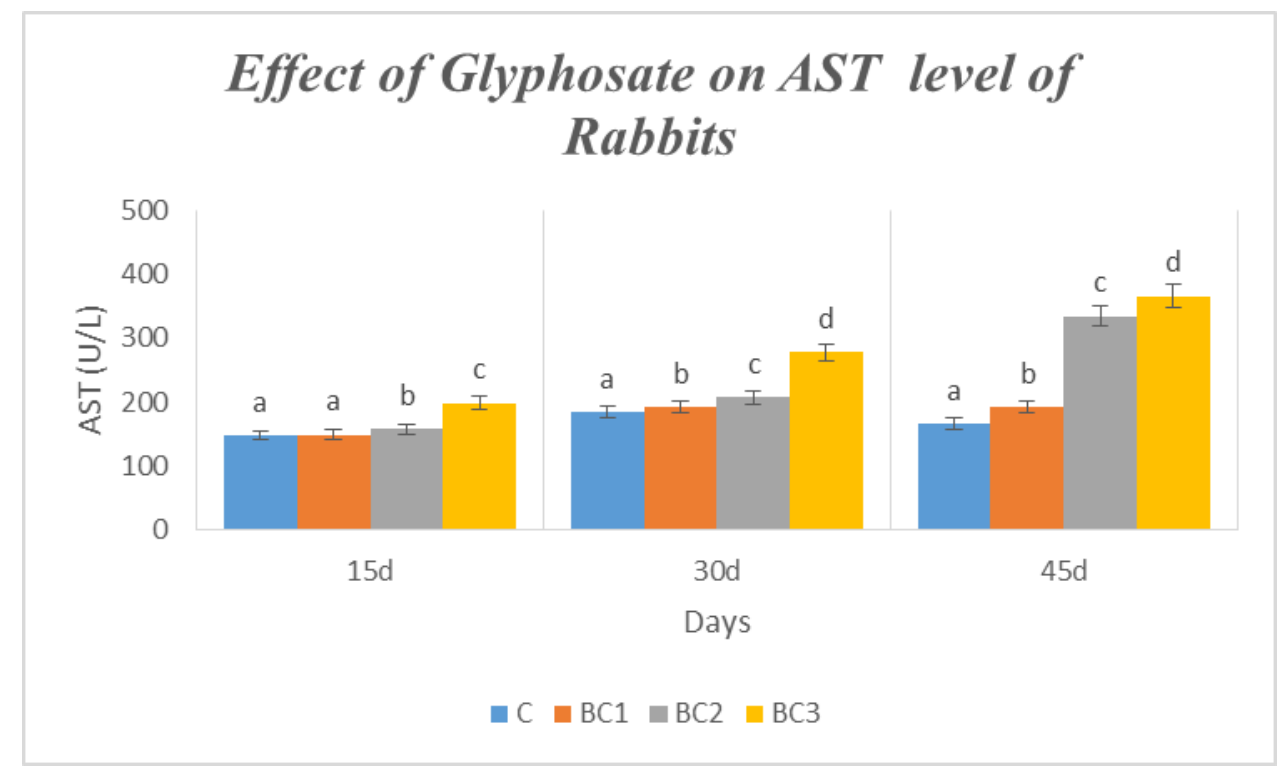

Figure 11. Aspartate aminotransferase (AST) level of rabbits in $\mathrm{C}$ (control) and different concentration groups BC1 $(50 \mathrm{mg} / \mathrm{kg} / \mathrm{bw}), B C 2(100 \mathrm{mg} / \mathrm{kg} / \mathrm{bw})$ and $B C 3(150 \mathrm{mg} / \mathrm{kg} / \mathrm{bw})$ of treatment $B$ (Glyphosate) at $15^{\text {th }}, 30^{\text {th }}$ and $45^{\text {th }}$ day. Bars with different letters are significantly different $(p \leq 0.05)$ 


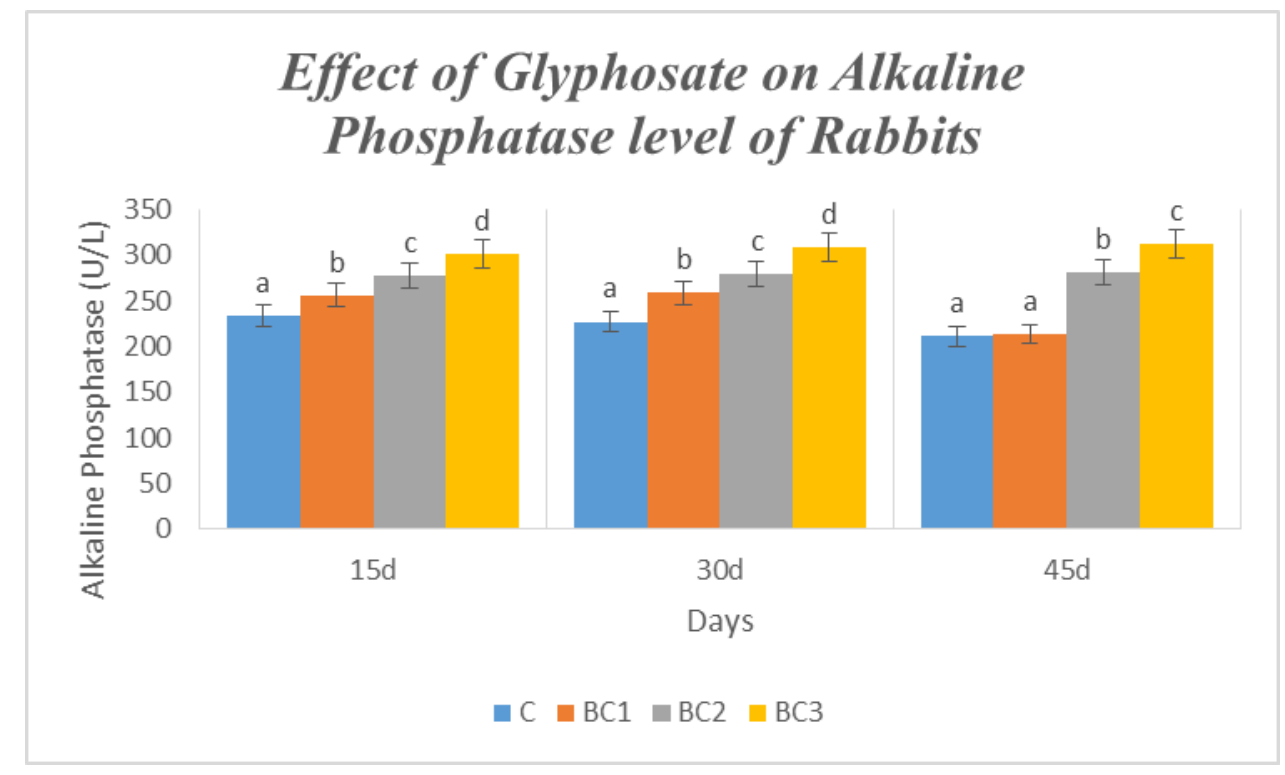

Figure 12. Alkaline phosphatase level of rabbits in $\mathrm{C}$ (control) and different concentration groups BC1 $(50 \mathrm{mg} / \mathrm{kg} / \mathrm{bw}), B C 2(100 \mathrm{mg} / \mathrm{kg} / \mathrm{bw})$ and BC3 $(150 \mathrm{mg} / \mathrm{kg} / \mathrm{bw})$ of treatment B (Glyphosate) at $15^{\text {th }}, 30^{\text {th }}$ and $45^{\text {th }}$ day. Bars with different letters are significantly different $(\mathbf{p} \leq \mathbf{0 . 0 5})$

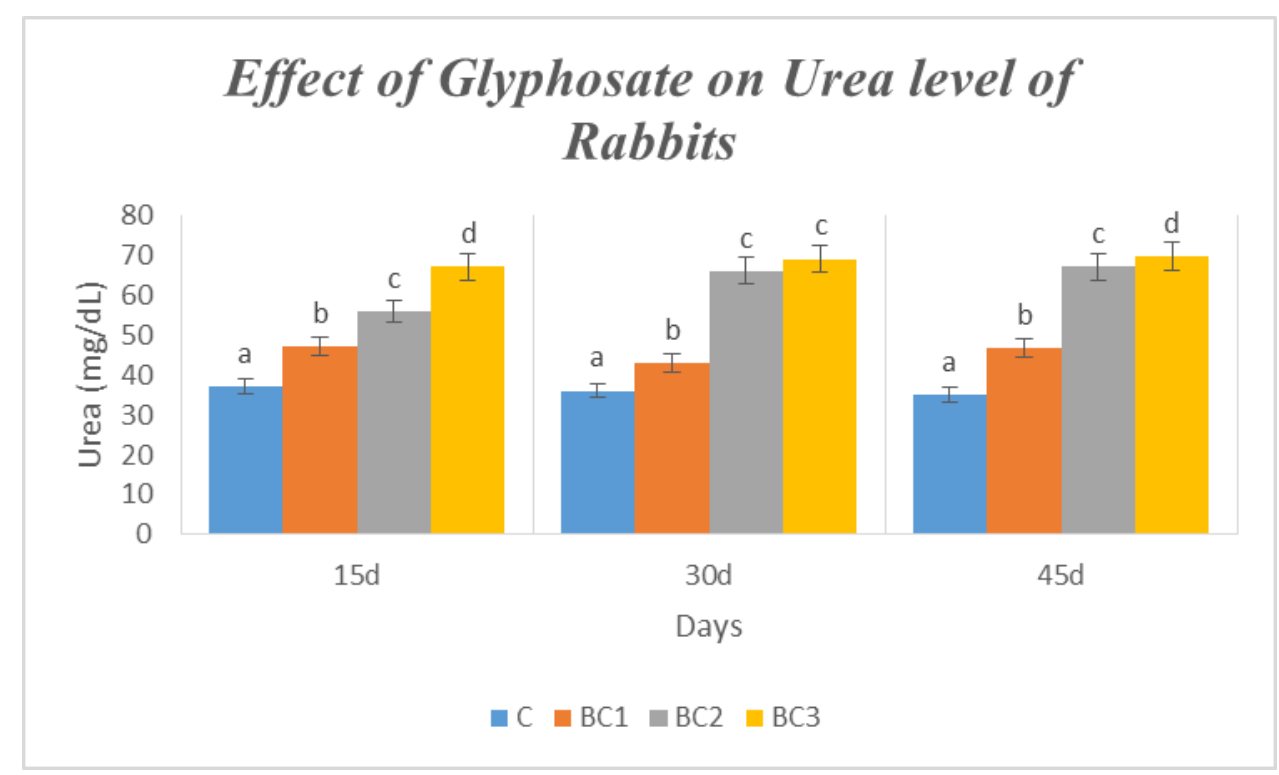

Figure 13. Urea level of rabbits in $\mathrm{C}$ (control) and different concentration groups $\mathrm{BC} 1$ $(50 \mathrm{mg} / \mathrm{kg} / \mathrm{bw}), B C 2(100 \mathrm{mg} / \mathrm{kg} / \mathrm{bw})$ and BC3 $(150 \mathrm{mg} / \mathrm{kg} / \mathrm{bw})$ of treatment B(Glyphosate) at $15^{\text {th }}, 3^{\text {th }}$ and $45^{\text {th }}$ day. Bars with different letters are significantly different $(p \leq 0.05)$ 


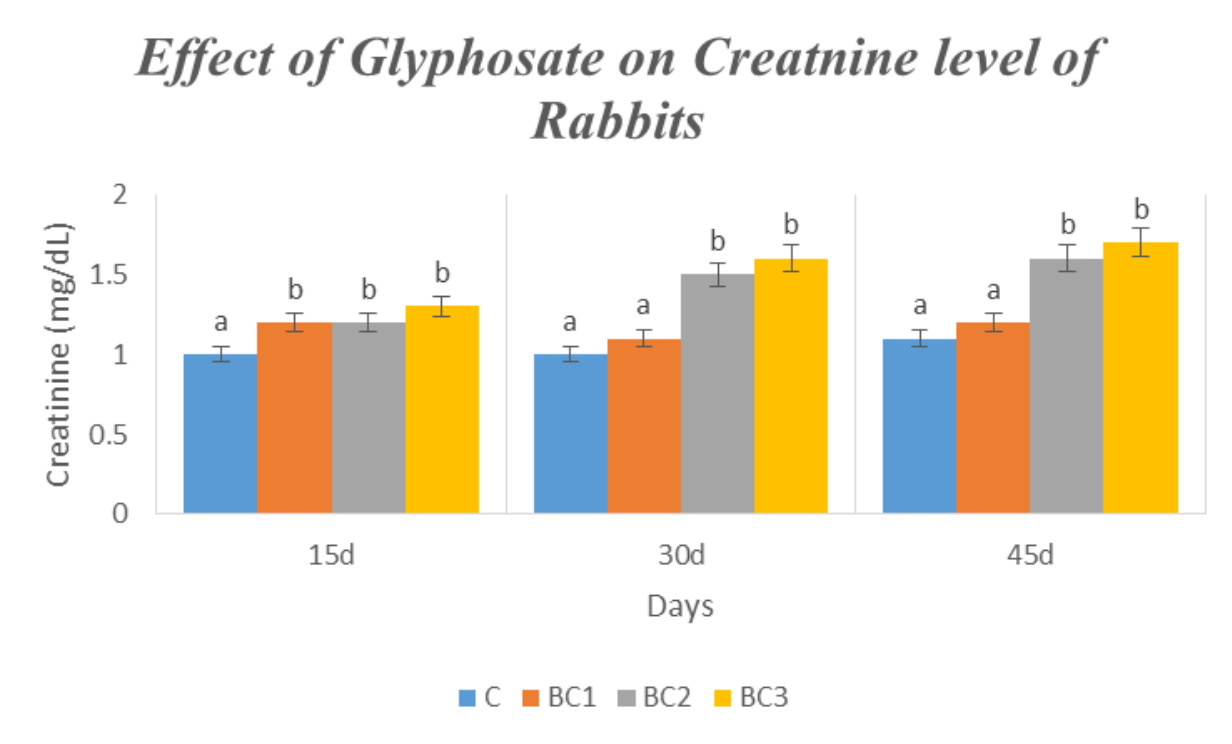

Figure 14. Creatinine level of rabbits in $\mathrm{C}$ (control) and different concentration groups $\mathrm{BC} 1$ $(50 \mathrm{mg} / \mathrm{kg} / \mathrm{bw})$, BC2 $(100 \mathrm{mg} / \mathrm{kg} / \mathrm{bw})$ and BC3 $(150 \mathrm{mg} / \mathrm{kg} / \mathrm{bw})$ of treatment B (Glyphosate) at $15^{\text {th }}, 30^{\text {th }}$ and $45^{\text {th }}$ day. Bars with different letters are significantly different $(p \leq 0.05)$

\section{Discussion}

For monitoring and diagnosing of any alteration in animal's body or blood damage investigation due to any toxicity or disease usually hematological parameters are considered. It refers to the study of numbers and morphology of the blood cells including red blood cells, white blood cells and platelets etc. [30-32]. These parameters are very important for diagnosing the physical condition of animals [33]. These parameters reflect the true picture of blood and blood forming organs $[34,35]$. Blood is a good indicator of pathological condition of an animal that are exposed to any toxic compound [36].

In present study red blood cells, hematocrits, hemoglobin, mean corpuscle volume, mean corpuscle hemoglobin, mean corpuscle hemoglobin concentration were significantly decreased for all concentrations as compared to control and this decrease was directly related to the increasing concentrations of herbicide and time of exposure. White blood cells and platelets were increased as compared to control. It was due to oxidative stress [37]. By exposure to any chemical there is erythroblast and resulting into decrease in HCT level. In anemic condition or hypoxia, decrease in hemoglobin level was observed in a study done by [38]. Immature neutrophils rise in blood was also experimented in rats. It was due to poisonousness strain in non-specific tissues follow-on production of free radicals and prostaglandins resulting inflammatory reaction by production of neutrophilia and lymphopenia [11]. According to a study [39] glyphosate and their metabolites cause hemolysis and hemoglobin oxidation and changing in erythrocytes increase with increasing concentrations. This change in erythrocytes was only due to the poisoning of chemicals. And cause genotoxicity in erythrocytes and gills cell in the fish [40].

According to a study [41] alanine aminotransferase (ALT or SGPT) and aspartate aminotransferase (AST or SGOT), which metabolize the amino acids vary from normal level and demonstrated as good pointers of hepatic toxicity. 
In current study, significantly elevation in bilirubin, alanine aminotransferase, aspartate aminotransferase, ALP, urea and creatinine level in treated groups as compared to control was observed. A study [42] also demonstrated such types of results in which significantly increase in AST, ALT, urea and creatinine level due to toxicity was observed as compared to control in rabbits. In another study, [43] the toxicity test is evaluated of diminazene aceturate on rats and significant increase in alanine aminotransferase, creatinine and urea level compared to control due to haptic and renal toxicity were observed. Similarly, the study [24] revealed there was elevation in AST, ALT and ALP level in female rabbits and slightly increase in bilirubin level and significant increase in urea and creatinine level in male rabbit due to toxicity.

\section{Conclusion}

Glyphosate showed remarkable toxicity for hematological and biochemical parameters and toxicity was directly related to the increasing concentration of glyphosate and time of exposure. There is need of more investigation at molecular level to know the mechanism of entry of glyphosate into the cells and how it interacts with vital cellular molecules.

\section{Authors' contributions}

Conceived and designed the experiments: $S$ Naz, R Iqbal \& MF Malik, Performed the experiments: S Naz \& R Yaqoob, Analyzed the data: S Naz \& M Jabbar, Contributed materials/ analysis/ tools: $M$ Saeed, A Hussain, T Aziz, SU Haider \& A Razaq, Wrote the paper:S Naz \& A Ahmed.

\section{References}

1. Chaufan G, Coalova I \& Molina MDCRD (2014). Glyphosate commercial formulation causes cytotoxicity, oxidative effects, and apoptosis on human cells: differences with its active ingredient. Inter J of Toxicol 33(1): 29-38.

2. Gaupp-berghausen M, Hofer M, Rewald B \& Zaller JG (2015). Glyphosate-based herbicides reduce the activity and reproduction of earthworms and lead to increased soil nutrient concentrations. Sci Rep 5: 12886.

3. Jallow MFA, Awadh DG, Albaho MS, Devi VY \& Thomas BM (2017). Pesticide risk behaviors and factors influencing pesticide use among farmers in Kuwait. Sci of the Total Environ 574: 490-498.

4. Lopes FM, Junior ASV, Corcini CD, Da silva AC, Guazzelli VG, Tavares G \& Da rosa CE (2014). Effect of glyphosate on the sperm quality of zebrafish Danio rerio. Aquatic Toxicol 155: 322-326.

5. Gilbert N (2013). A hard look at GM crops. Nature 497(7447): 24.

6. Balbuena MS, Tison L, Hahn ML, Greggers U, Menzel R \& Farina WM (2015). Effects of sublethal doses of glyphosate on honeybee navigation. $J$ of Exper Biol 218(17): 2799-2805.

7. Clair E, Linn L, Travert C, Amiel C, Séralini GE \& Panoff JM (2012). Effects of Roundup ${ }^{\circledR}$ and Glyphosate on Three Food Microorganisms: Geotrichum candidum, Lactococcus lactis subsp. cremoris and Lactobacillus delbrueckii subsp bulgaricus. Curr Microbiol 64(5): 486-491.

8. Diamand E \& Barron H (2001). Health and environmental impacts of glyphosate. Report. Pesticide Action Network UK.

9. Krüger M, Schledorn P, Schrödl W, Hoppe HW, Lutz W \& Shehata AA (2014). Detection of glyphosate residues in animals and humans. J of Environ \& Analy Toxicol 4(2): 1.

10. Gasnier C, Dumont C, Benachour N, Clair E, Chagnon MC \& Séralini GE (2009). Glyphosate-based herbicides are toxic and endocrine disruptors in human cell lines. Toxicol 262(3): 184-191.

11. Khan AM, Dubey N, Raina R, Singh G \& Beigh SA (2013). Toxic effects of deltamethrin and fluoride on hematological parameters in rats. Fluoride 46(1): 34-38. 
12. Benachour N \& Séralini GE (2008). Glyphosate formulations induce apoptosis and necrosis in human umbilical, embryonic, and placental cells. Chem Res in Toxicol 22(1): 97-105.

13. Benachour N, Sipahutar H, Moslemi S, Gasnier C, Travert C \& Séralini GE (2007). Time-and dose-dependent effects of roundup on human embryonic and placental cells. Archives of Environ Contamination and Toxicol 53(1):126133.

14. Defarge N, Takács E, Lozano VL, Mesnage R, Spiroux de vendômois J, Séralini GE \& Székács A (2016). Coformulants in glyphosate-based herbicides disrupt aromatase activity in human cells below toxic levels. Inter $J$ of Environ Res and Public Health 13(3): 264.

15. Richard S, Moslemi S, Sipahutar H, Benachour N \& Seralini GE (2005). Differential effects of glyphosate and roundup on human placental cells and aromatase. Environ Health Pers 113(6): 716.

16. Pieniazek D, Bukowska B \& Duda W (2002). Glyphosate--a non-toxic pesticide? Medycyna Pracy 54(6): 579583.

17. Samsel A \& Seneff S (2015). Glyphosate, pathways to modern diseases IV: cancer and related pathologies. J Biol Phys Chem 15: 121-159.

18. Paz-y-miño C, Sánchez ME, Arévalo M, Muñoz MJ, Witte T, De-la-carrera GO \& Leone PE (2007). Evaluation of DNA damage in an Ecuadorian population exposed to glyphosate. Genetics and $\mathrm{Mol}$ Biol 30(2): 456-460.

19. Mesnage R, Arno M, Costanzo M, Malatesta M, Séralini GE \& Antoniou MN (2015). Transcriptome profile analysis reflects rat liver and kidney damage following chronic ultra-low dose Roundup exposure. Environ Health 14(1): 70.

20. Webster TMU \& Santos EM (2015). Global transcriptomic profiling demonstrates induction of oxidative stress and of compensatory cellular stress responses in brown trout exposed to glyphosate and Roundup. BMC Gen 16(1): 32.

21. Whary M, Peper R, Borkowski G, Lawrence W \& Ferguson F (1993). The effects of group housing on the research use of the laboratory rabbit. $L a b$ Anim 27(4): 330-341.

22. Talbot AR, Shiaw MH, Huang JS, Yang SF, Goo TS, Wang SH, Chen CL \& Sanford TR (1991). Acute poisoning with a glyphosate-surfactant herbicide ('Roundup'): a review of 93 cases. Human \& Exper Toxicol 10(1): 1-8.

23. Mehjabeen, Farah-saeed, Noor J \& Ahmad M (2015). Investigations on A. mellifica extract on the hematological, biochemical evaluate on, urine analysis and histopathological parameters of white albino rabbits. Inter $J$ Pharm Pharmaceutical Sci 7(5): 127-129.

24. Vick HA (1977). Automatic hematology analyzer. Hycel, Inc., U.S. Patent 4,052,596.

25. Ghazy AE, Gomaa NA \& Nasr NE (2016). Hematological and Biochemical Evaluation in Holstein-Friesian Cows Before and After Surgical Correction of Left Abomasal Displacement on-Filed Condition. Alexandria J of Vet Sci 49 (1): 138-146.

26. Malloy HT \& Evelyn KA (1937). The determination of bilirubin with the photoelectric colorimeter. $J$ of Biol Chem 119(2): 481-490.

27. Yatzidis H (1977). An improved biuret reagent. Clinical Chem 23(5): 908-908.

28. Talke H (1965). Enzymatic determination of urea in blood and serum with the optical test according to Warburg. Kiln Wschr 43: 174-175.

29. Jeffe M (1886). Z Physiol Chem, 10: 391.

30. Merck M (2012). Hematologic reference ranges. Mareck Veterinary Manual.

31. Onyeyelli PA, Egwu GO, Jibike GI, Pepple DJ \& Ohaegbulam JO (1991). Seasonal variations in haematological indices in the Grey Breasted Guinea Fowl (Numida Meleagris Galeata 
Pallas). Nigerian $J$ of Animal Production 18(1): 108-110.

32. Togun VA, Oseni BSA, Ogundipe JA, Arewa TR, Hammed AA, Ajonijebu DC \& Mustapha F (2007). Effects of chronic lead administration on the haematological parameters of rabbits. In Proceedings of 41 st Conferences of the Agricultural Society of Nigeria, 341.

33. Khan TA \& Zafar F (2005). Haematological study in response to varying doses of estrogen in broiler chicken. Inter J of Poultry Sci 4(10): 748751.

34. Bamishaiye EI, Muhammad NO \& Bamishaiye OM (2010). Haematological parameters of albino rats fed on tiger nuts (Cyperus esculentus) tuber oil meal-based diet. Inter $J$ of Nutrition and Wellness 10(1).

35. Waugh A \& Grant A (2010). Ross \& Wilson Anatomy and Physiology in Health and Illness E-Book. $9^{\text {th }}$ edition. Elsevier Health Sci, pp 59-71.

36. Olafedehan CO, Obun AM, Yusuf MK, Adewumi OO, Oladefedehan AO, Awofolaji AO \& Adeniji AA (2010). Effects of residual cyanide in processed cassava peal meals on haematological and biochemical indices of growing rabbits. In Proc of 35th Ann Conf of Niger Soc for Anim Prod 2: 212.

37. George J \& Shukla Y (2013). Emptying of intracellular calcium pool and oxidative stress imbalance are associated with the glyphosate-induced proliferation in human skin keratinocytes $\mathrm{HaCaT}$ cells. ISRN Dermatol.

38. Zorriehzahra MJ, Hassan MD, Gholizadeh M \& Saidi A.A (2010). Study of some hematological and biochemical parameters of Rainbow trout (Oncorhynchus mykiss) fry in western part of Mazandaran province, Iran. Iranian J of Fisheries Sci 9(1): 185-198.

39. Kwiatkowska M, Huras B \& Bukowska B (2014). The effect of metabolites and impurities of glyphosate on human erythrocytes (in vitro). Pesticide Biochem and Physiol 109: 34-43.

40. Moreno NC, Sofia SH \& Martinez CB (2014). Genotoxic effects of the herbicide Roundup Transorb ${ }^{\circledR}$ and its active ingredient glyphosate on the fish Prochilodus lineatus. Environ Toxicol and Pharmacol 37(1): 448-454.

41. Bálint T, Ferenczy J, Kátai F, Kiss I, Kráczer L, Kufcsák O, Láng G, Polyhos C, Szabó I, Szegletes T \& Nemcsók J (1997). Similarities and differences between the massive eel (Anguilla anguilla) devastations that occurred in Lake Balaton in 1991 and 1995. Ecotoxicol and Environ Safety 37(1):17-23.

42. Sarhan OMM \& Al-sahhaf ZY (2011). Histological and biochemical effects of diazinon on liver and kidney of rabbits. Life Sci J 8(4): 1183-9.

43. Oliveira CB, Rigo LA, Franca RT, Gressler LT, Dalla rosa L, Ourique AF, Oliveira DT, Doyle RL, Dos santos moreira KL, Veiga ML \& Lopes ST (2014). Diminazene Aceturate Liposomes: Morphometric and Biochemical Liver, Kidney, and Spleen of Rats Infected with Trypanosoma evansi. Pathol Res and Prac 210(12): 840-846. 